\title{
Decarbonization and regulation of Germany's electricity system after Fukushima
}

Originally published as:

Stefan Lechtenböhmer, Hans-Jochen Luhmann (2013):

Decarbonization and regulation of Germany's electricity system after Fukushima In: Climate Policy Special Issue: Low Carbon Drivers for a Sustainable World, 13, sup01, 146-154

DOI: $10.1080 / 14693062.2013 .754605$ 
Stefan Lechtenböhmer ${ }^{*}$, Hans-Jochen Luhmann

\section{Decarbonization and regulation of Germany's electricity system after Fukushima}

Wuppertal Institute for Climate, Environment and Energy, Germany

* Corresponding author: Stefan Lechtenböhmer, Wuppertal Institute for Climate, Environment and Energy, Döppersberg 19, 42103 Wuppertal, Germany

E-mail: stefan.lechtenboehmer@wupperinst.org

Phone: $+49-202-2492216$

Fax: +49-202-2492-198 


\title{
Decarbonisation and regulation of Germany's electricity system after Fukushima
}

\begin{abstract}
Germany's current efforts to decarbonise its electricity system are analyzed. As nuclear power and fossil power equipped with carbon capture and storage were ruled out in 2011 renewable electricity generation (RES) together with electricity savings remain for achieving decarbonisation. Germany aims to have RES account for at least $80 \%$ of its electricity by 2050 . Achieving renewable generation needs strong political support and regulatory provisions for its market integration. Four main technical and regulatory challenges are: the maintenance of a steady and efficient expansion of RES, the provision of balancing capacities, the realisation of the targeted electricity savings, and the smart adaptation of the transport and distribution grid. An overview of the existing and planned regulatory provisions for decarbonisation are described, and some gaps identified, particularly with regard to the overall management of the process, the inclusion of electricity savings and the interference of Germany's decarbonisation strategies with neighbouring countries. Policies that both accelerate grid expansion and direct RES expansion should immediately be put in place and can be supported by a targeted mobilization of balancing capacities. Electricity savings are a significant and cost-efficient strategy for low-carbon electricity.
\end{abstract}

\section{Policy relevance}

Germany is actively converting the national electricity system towards a fully renewable one. As renewable electricity has reached about a quarter of total consumption a number of technical and regulatory challenges arise. The paper sketches current discussions and plans on the four main challenges which are: maintaining and optimising high investment rates into RES generation technologies, providing balancing capacities, saving electricity and adapting the grid to the changing needs. The paper concludes with policy recommendations on those four tasks, highlights the need to intensify electricity savings and briefly sketches potential interferences of the trends in the German electricity system with those of neighbouring countries.

Keywords: electricity markets; electricity sector; market structure; regulation; regulation framework; renewable energy. 


\section{Introduction}

In autumn 2010, the German Federal Government envisaged a low carbon future based on a combination of $10 \%$ electricity savings relative to 2008 by 2020 (25\% by 2050) and the use of all three low-carbon electricity generation technology groups (LCEGTs). ${ }^{1}$ Energy from renewable sources (RES) as defined in the EU's EED were set to deliver $35 \%$ of gross electricity consumption by $2020,50 \%$ by $2030,65 \%$ by 2040 , and $80 \%$ by 2050 , together with prolonged lifetimes of nuclear power plants (NPPs), which were seen as a 'bridge' to a low-carbon electricity system. By 2020 , the German government also aimed to implement 2 of the 12 CCS demonstration projects that the EU had pledged to support.

However, in 2011, one of the three LCGETs - RES - became the only viable option for Germany. The Energiewende triggered by the Japanese nuclear catastrophe heralded the end of NPPs in Germany. ${ }^{2}$ Between June and July 2011, several laws were passed, which led to the final shutdown of the 8 NPPs already mothballed since March 2011 and stipulated concrete termination dates for the licenses of the remaining 9 NPPs. The last two NPPs will stop operating by the end of $2022^{3}$ at the latest.

During this same time (and coincidentally), CCS, which had already been in trouble for years, suffered a severe blow. A first attempt to implement the EU CCS directive into national law had already failed in Summer 2010 due to strong resistance from those states in which potential storage facilities are located. A more cautious draft law from April 2011 has not yet been passed and legal certainty for CCS investment is still lacking (Viebahn, Vallentin, Höller, \& Fischedick, 2011). In response, Vattenfall closed the last existing German CCS pilot plant in December 2011 (Resenhoeft, 2011). In other EU countries the prospects of CCs also look rather cloudy (von Hirschhausen, Herold, \& Oei, 2012).

Surprisingly, in spite of the loss of two LCGETs, the Government did not increase its aspirational RES targets. This was done instead by the German parliament, which made only one essential adjustment to the package of laws: it altered the wording of the Renewable Energy Law (EEG) used to describe the target share of RES in electricity production from ' $80 \%$ by 2050 ' to 'at least $80 \%$ by 2050 at the latest' and the equivalent for the other RES targets (see EEG 2011, §1(2)). ${ }^{4}$

Consequently, many of the states, partly triggered by the Fukushima effect, started to compete to attract RES generation to both add value and channel financial resources from the federal financing scheme to their territories. Overall, they substantially increased their respective targets for RES expansion (BNetzA 2011a, dena 2011) and are starting to improve the financial prospects for RES investments by streamlining planning procedures and revising legal requirements. The states are currently targeting RES growth that could - depending on demand - lead to the supply by renewable electricity of almost $50 \%$ of Germany's electricity demand as early as 2020. For the purposes of planning its grid expansion, the German Federal Network Agency (BNetzA 2011a), who is the federal grid regulator, used a figure of

\footnotetext{
${ }^{1}$ See Bundesregierung 2010. See also Nagl et al. (2011) who describe the scenario analysis that they carried out as a basis for the Government's decision.

2 For more details on Germany's nuclear policy before and after Fukushima, see e.g. Wittneben (2011), Jahn/Korolczuk (2012) or Bosman (2012).

th

313 act to amend the Atomic Energy Act

${ }^{4}$ According to several studies German RES-potentials from on- and offshore wind, solar and biomass are sufficient to achieve 100\% RES electricity generation from domestic sources (see e.g. Nagl et al, 2011, SRU 2010).
} 
over $60 \%$ by 2032 as the most 'probable' basic assumption. This is a path well beyond the stated aims of the German government.

It is concluded from these (ambivalent) experiences that the expansion of RES electricity has already achieved a self-sustaining dynamic in Germany. This dynamic is being driven by competing political actors (who remove barriers and build infrastructures), and the well-known forms of competition between companies that result in technological progress and, consequently, decreasing technological costs. ${ }^{5}$

\section{Four main regulatory challenges for low carbon electricity}

Whether or not Germany will achieve the expected share of RES electricity, its robust expansion is forcing the rapid transformation of the German electricity system. This transformation, given the outstanding complexity of its subject, is in itself a huge management challenge. In addition, there are four main technical and regulatory challenges:

(i) How to continue the steady and efficient ${ }^{6}$ expansion of renewable generation capacities without increasing the need for balancing capacity to an unjustified or even unfeasible level,

(ii) How to provide balancing capacities from several origins, not only from conventional power plants, in a non-discriminatory way, as is necessary in the short term (assuring frequency stability) and in the mid term (to bridge possible capacity gaps in times of insufficient RES supply),

(iii) How to achieve the targeted electricity savings, and

(iv) How best to adapt the grid to enable the targeted expansion of RES electricity by both increasing the capacities of the transport grids and enabling intelligent use of distribution networks ('smart grid').

Meeting these major technical challenges is the core regulatory target in Germany. However, it should be noted that challenge (iii) - i.e. saving electricity by improving efficiency - is not even yet being discussed in a regulatory context, even if demand side management (DSM) is a subject.

\subsection{Efficient expansion of RES capacities}

While the Renewable Energy Law has proven very effective in increasing RES electricity to more than $20 \%$ of German gross demand (and is on track to comprise $40 \%$ to $50 \%$ by 2020) the efficiency of the transformation is increasingly urgent. The challenge is to ensure that a further expansion of contributions from volatile sources does not create inefficiency and overly high costs in terms of grid expansion, the development of balancing capacities, and/or disconnecting RES generation in times of grid combustion.

Priority grid access ${ }^{7}$ and the fixed feed-in tarifs (FIT) granted by the

\footnotetext{
${ }^{5}$ This assumption is supported by the heavy and successful campaign that PV manufacturers ran in spring 2012 against additional cuts of the guaranteed feed-in tarrifs under the Renewable Energy Law.

6 'Efficient' means in this context: 'investment into' renewable 'generation at sites where it is most valuable and least expensive for society' (adapted from Vogel, 2009, p. 3666). We do not aim here at a discussion about the preference for any RES technology. Existing regulations were originally drafted to support a range of technologies to enable technology development and a mix of generation options. How this regulatory system will evolve is a different topic.

${ }^{7}$ In general, contributions from sources with zero marginal cost already have priority access due to European competition law. The guarantee of priority access in the German Renewable
} 
Renewable Energy Law are the main political instruments that influence RES capacity expansion. ${ }^{8}$ Setting fixed feed-in rates for specific technologies, e.g. photovoltaics, wind or biomass, influences technology choice. The German parliament has already used this with regards to the RES technology portfolio: it has significantly decreased rates for photovoltaics and increased support for off-shore wind. Additional measures, e.g. to incentivise initial investment into off-shore wind power, have also been introduced. However, this process has been slow and, being at the forefront of public and economic interest, is also subject to intense political debate. ${ }^{9}$

While reducing feed-in rates may be effective in slowing down the growth rates of certain technologies, the tools provided to determine where capacity growth should be located capacity growth are weak and indirect. For the integration of distributed generation from RES into distribution grids, distribution grid operators would be entitled to apply 'deep charges' for grid connections which are full cost-oriented (Vogel, 2009, p. 3671) or smart contracts containing locational elements (Brandstätt, Brunekreeft, \& Friedrichsen, 2011). There is already a device for large scale geographic steering: the differentiated FIT rate for on-shore wind at low wind sites. This instrument could be further developed to incentivise capacity development in southern Germany's low wind regions and, potentially, to slow down development in the already highly developed high wind sites of northern Germany.

\subsection{Provision of balancing capacities}

In a landmark paper on the 'smart grid' and the 'smart market', the German Federal Network Agency (BNetzA 2011b) provided the conceptual basis for a stakeholder discussion on core regulatory challenges. In particular, it outlined its preferences in terms of the complementary nature of markets and market-enabling provisions: on the one hand, there is the 'infrastructure' (mainly grid expansion and improvement, but also as general definition of basic products or cases), which should be provided centrally; on the other hand there is the 'balancing capacity' (differentiated according to several characteristics), which the markets should provide. The subjects of the provision are, accordingly, the regulator and a manifold of economic subjects. Even if the regulator were to be generally assisted by private enterprises, it would essentially be a public service which was provided here.

The conceptual foundation for this approach was transferred from the IT sector in which it is common to distinguish between one 'platform' and (many) 'use cases' to be provided at the platform installed. The public service would thus be restricted to enabling the provision of capacities that do contribute to the balancing task by market-driven processes, including all possible suppliers, in a non-discriminatory manner.

The main consequence of the BNetzA-paper was to abandon the unilateral notion that the only 'possible suppliers' of electricity are the traditional electricity producers. Instead, the German Federal Network Agency introduced a new third party standing between producers and consumers, known as 'prosumers'. As prosumers, electricity-consuming agents supply their respective balancing capacities according to their capabilities of demand management or decentralised production. Large consumers may do this on their own or this may be controlled for e.g. household consumers or electric car users in a coordinated manner by a specialised agent (Schleicher Tappeser, 2012; Verbong, Beemsterboer, \& Sengers, 2012)

Energy Law is only a confirmation.

${ }^{8}$ For a brief description of the principles of the Renewable Energy Law see e.g. Langniß, Dieckmann, \& Lehr, $(2009,1290 f)$.

${ }^{9}$ See Note 8 
In the existing incentive system, regional differences are not taken into account as grid operators provide regional balancing under the public service umbrella. The fiction of 'automatic' regional balancing is obviously unrealistic. Regional balancing comprises of two different but increasingly important tasks. At the macro-level, an increasing amount of electricity has to be physically transported from the mainly northern sources to the consumers mainly in the south. This can be solved by improving the transport capacities of the grid. At the micro-level, the vast majority of the new renewable generation from on-shore wind, photovoltaic and biomass is already fed into distribution grids. With an increasingly decentralized generation at the micro-level, 'smart' regional balancing becomes particularly important if inefficient or even unfeasible demands on the grid are to be avoided.

The regulatory consequence of the latter, as explored by the Federal Grid Agency (BNetzA 2011b), is to decrease the complexity of the system in Germany, which is now split into four TSO regions, by splitting it on a second level into regional 'cells'. These cells, in principle, can provide and optimise their internal balance (at every point in time) and communicate with the general system's grid dispatcher only with respect to remaining or intentional deficiencies or surpluses. ${ }^{10}$

Nevertheless, it is highly likely that it will be necessary to actively provide for large-scale compensating capacities. Options for these capacities are manifold and must be carefully selected and designed according to both the phase in the transformation process in which they are needed and the regional differences and potential lack of capacity. For this purpose, the regulator (BNetzA) is relying on a legal provision. ${ }^{11}$ If the security of the system seems to be endangered, the regulator is entitled to call for tender for the construction of compensating capacities according to its specification. This instrument is currently predominantly conceptualized with regards to supply side balancing capacities. Measures that aim to make electricity savings, or those which encourage supply of balancing services by prosumers, are, however, equivalent to a capacity increase, i.e. they can also be made subject of a tendering procedure.

\subsection{Negawatt as LCE(G)T}

Given the targets identified by the German Government, electricity savings, or in supply-side wording 'Negawatts', must significantly contribute to a low-carbon electricity system (FRG, 2010). These 'net' targets are particularly ambitious as they include increasing electricity demand for heating purposes (heat pumps) and electric vehicles.

Although Negawatts and DSM, e.g. in industry (as analysed by Paulus \& Borggrefe, 2011), have not yet been identified as a core regulatory task, the Federal Grid Agency could use the energy law regulation to call for tenders for DSM schemes to provide balancing capacity. These should however be integrated with targeted programmes to induce absolute electricity savings in all the demand segments that are currently targeted mainly by EU-wide instruments such as the eco-design directive.

Another possible policy option for DSM that is currently being assessed, particularly for electricity savings, would be to introduce energy efficiency obligations and/or white certificates. ${ }^{12}$ Under this model, which has already been implemented in

\footnotetext{
${ }^{10}$ See e.g. Fouquet $(2012,3 f)$ who sketches a picture of intelligent and distributed systems based on zero net energy consuming households as an important step to phase in renewable energies.

11 As mandated by the Energy Law (§ 53 EnWG).

12 'Zudem wird die Bundesregierung prüfen, ob 2015 eine haushaltsunabhängige Lösung (z.B.
} 
the UK and several other EU countries, energy supply or distribution companies are obliged to promote and stimulate investment and other measures in order to achieve verifiable energy savings for their customers (Bertoldi \& Huld, 2004; Bertoldi \& Rezessy, 2009; Bertoldi et al., 2010).

\subsection{Grid upgrading as a public service}

Higher shares of fluctuating renewable generation from wind and solar will in general affect the capacities of the grid, especially at strategic grid nodes. To optimise the interaction between location of production and grid ressources - scarcity-based grid tariffs are discussed as a preferred instrument. These tend to be effective when managing scarce resources but are subject to strong limitations when it comes to efficient expansion of infrastructure. The latter is, however, necessary to enable the planned high share of RES. Therefore, the Federal Grid Agency has regarded the transformation of the grid as a public service ${ }^{13}$. The grid is thus 'only' an enabler for markets to trade various electricity products and scarcity based grid tariffs are not regarded as appropriate instrument.

To make the markets work, bottlenecks in the grid must be avoided, i.e. the grid's capabilities must be improved and, to some extent, overcapacities must be allowable (BNetzA, 2011a). This can be achieved by an extension of the transport capacities of the long distance high-voltage grid in order to avoid bottlenecks and to enable electricity transport (mainly from northern sources to southern consumers). This can be achieved by conventional solutions and include better management of existing capacities, the extension of existing routes, e.g. by adding ropes or cables and by investment in new routes with conventional high-voltage technology or with new high voltage direct current transmission technology (BNetzA, 2011b). The distance of new lines needed is, however, a matter of great debate. Studies predict that between $500 \mathrm{~km}$ (Consentec, 2011) and $3600 \mathrm{~km}$ (dena, 2010) of new high voltage lines will be required in Germany by 2020 .

The distribution grids, on the other hand, must be upgraded in order to better handle varying, and partially reversed, electricity flows. The main way of achieving this is to make them 'smart', e.g. by applying intelligent components and monitoring load flows (BNetzA, 2011b; Clastres, 2011).

The German Government (FRG, 2010) has identified grid improvements as a major challenge for achieving a low-carbon electricity system in Germany. As part of the implementation of the energy concept, a law to accelerate grid extension (NABEG, 2011) was passed and the Federal Grid Agency was entrusted with additional competencies relating to the planning process of electricity grids (BNetzA, 2011b).

As a first step BNetzA set up an 'approved scenario framework' that outlined the expected range over the next ten to twenty years (until 2022 and 2032) of RES capacity expansion, regionally determined down to a cell level, and the overall electricity demand (BNetzA, 2011a). The scenario framework will result in a binding federal grid requirement plan, to be revised annually. This procedure has formed the basis for a newly introduced federal planning process of routes and concrete locations of new transmission lines (BNetzA, 2011b).

weiße Zertifikate) eingeführt werden kann.' (Bundesregierung, 2011), which can be translated as 'Additionally, the German Federal Government will check, if in 2015 a solution without budget impact (e.g. white certificates) could be introduced)'.

${ }^{13}$ In order to establish additional long-distance electricity transport capacity, the model of a state-owned grid company has also been discussed. This could be formed from the existing state-owned nationwide transmission grid of German Rail (DB Netz). This option, however, does not currently seem to be actively promoted. 


\section{Conclusion}

Achieving a low-carbon electricity system is high on the German political agenda. In autumn 2010 the government decided on a low-carbon plan until 2050, while 2011 heralded a clear decision to pursue this pathway almost exclusively through the use of RES generation (and electricity savings). Despite still facing major transitional challenges, this strategy can build upon the strong dynamics of RES expansion in the German market that have been created mainly by the supporting system in place since 1991. Consequently, Germany currently faces four main regulatory tasks.

First, the efficiency of the already very effective regulation for the expansion of RES capacities must be improved to achieve an expansion pathway that is better adapted to the overall electricity system's needs with regards to the temporal and spatial harmonisation of RES production. Most influential for this change will be the provisions of the Renewable Energy Law, which regulates the FIT rates and other incentives for RES capacity expansion. The provisions have already been amended, by setting an overall ceiling to (FIT-induced) PV capacity in Germany and by differentiating wind FIT rates according to onshore and offshore origin. The latter can be seen as a first step towards a more large-scale regional discrimination of FIT rates. The distribution system operators should develop models such as flexible 'smart' contracts for an optimised steering of capacities on the regional level mechanisms.

Second, a market-oriented non-discriminatory supply of balancing capacities of all types needs to be managed, including decentralized generation, demand-side options and storage. Investment into additional capacities should be stimulated as and where required. The vision developed and submitted by the regulator is to create regional 'cells', comparable to platforms in the telecommunications sector, to form and provide marketplaces. The incentives from these will provoke decentralized balancing of supply and demand. Large-scale balancing capacities will, can and should be provided by the tendering process already in place, but could be expanded to include DSM options.

Third, effective policy and regulation for DSM and electricity savings (Negawatts) should be implemented. The German Government, however, still lacks a clear strategy and has not yet been fully integrated into the Federal Grid Agency's regulatory portfolio. The main option for implementing policy and regulation in this case is the tendering procedure for balancing capacity, which could be used to call for tender for DSM programmes and ideally would be combined with electricity savings programmes for all demand segments or the introduction of white certificates.

Fourth, the grid capability must be improved to make it an enabler of the aspired change instead of a potential bottleneck. This is probably the most urgent task in need of action. Significant investment into new high-voltage long distance lines must be made by the TSOs while the distribution grids must become 'smart'. With respect to additional transport capacities, an accelerated planning procedure with respective powers - mainly for the Federal Grid Agency - has already been put in place and the first steps in the process have already been taken. The main issue now is how to sensibly plan and implement the necessary investments to achieve acceptance of the corridors, which is a prerequisite for the successful and faster expansion of grids relative to recent years.

There is an urgent need to balance the existing electricity network, which is currently under critical conditions given the fast increasing shares of RES, and the reduced capacity of conventional power. Thus, policies that both accelerate grid expansion and direct RES expansion in a way more in line with Germany's overall system's needs should be immediately put in place and used effectively in the coming months and years. A targeted mobilization of balancing capacities, including DSM, can support very quickly and may be needed to avoid friction in the short and medium term. Electricity savings are a significant and cost-efficient strategy for low-carbon 
electricity. Exploiting them however is more of a long-term task but is one that has some potential to mitigate the short-term challenges.

Whether these strategies will deliver the desired effect on neighbouring electricity markets remains an open question. With a growing RES share Germany will increasingly offer low or zero (marginal) cost green electricity on neighbouring countries' markets. Due to the liberalized market regime in the EU, this electricity has the potential to outcompete both base-load oriented fossil power plants with CCS and the nuclear options and will, therefore, affect their economic performance - restricted by the amount of trans-border capacity, of course. Production from these baseload LCEGTs will have to be reduced or even switched off more frequently in times of high RES production or, if they continue constant production, they will face times of negative revenues. This potential for conflict is already relevant but will grow in importance over the coming five to ten years. This indicates the need for international coordination, at least at the level of direct neighbourhood.

Overall, Germany seems poised to follow the renewables path to a low- carbon electricity system. Regulation to stimulate the necessary generation investment is already in place and operating effectively. The critical challenge is now to steer system integration from the current levels of $20 \%$ RES electricity to the expected $40 \%$ to $50 \%$ by 2020 and beyond.

\section{References}

Bertoldi, P. \& Huld, T. (2004). Tradable certificates for renewable electricity and energy savings. Energy Policy, 34(2), 212-222.

Bertoldi, P. \& Rezessy, S., (2009). Energy Saving Obligations and Tradable White Certificates (Report). Brussels: Joint Research Centre, European Commission.

Bertoldi, P., Rezessy, S., Lees, E., Baudry, P., Jeandel, A., \& Labanca, N. (2010). Energy supplier obligations and white certificate schemes: comparative analysis of experiences in the European Union. Energy Policy, 38(3),14551469.

BNetzA. (2011a). Administrative decision of the scenario outlook (English translation)http://www.netzausbau.de/SharedDocs/Downloads/EN/Administrati ve $\% 20$ decision $\% 20$ of $\% 20$ the $\% 20$ scenario\%20utlook\%20in\%20English.pdf?

blob=publicationFile

BNetzA. (2011b). "Smart Grid" und "Smart Market". Eckpunktepapier der Bundesnetzagentur zu den Aspekten des sich verändernden Energieversorgungssystems, Bonn. Retrieved from http://www.bundesnetzagentur.de/SharedDocs/Downloads/DE/BNetzA/Sachg ebiete/Energie/Sonderthemen/SmartGridEckpunktepapier/SmartGridPapierpdf .pdf?_blob=publicationFile

Bosman, R. (2012). Germany's 'Energiewende'. Redefining the Rules of the Energy Game (Briefing Paper)., The Hague: Clingendael. Retrieved from http://www.clingendael.nl/publications/2012/20120215_ciep_briefingpaper_rbo sman_germany_energiewende.pdf.

Brandstätt, C., Brunekreeft, G., \& Friedrichsen, N. (2011). Locational signals to reduce network investments in smart distribution grids: What works and what not? Utilities Policy, 19, 244-254.

Bundesregierung. (2010). Energiekonzept für eine umweltschonende, zuverlässige und bezahlbare Energieversorgung. Decision as of 28 September 2010

Bundesregierung (2011), Der Weg zur Energie der Zukunft - sicher, bezahlbar und umweltfreundlich. Cabinet decision as of 6 June 2011. 
Clastres, C. (2011). Smart grids: Another step towards competition, energy security and climate change objectives. Energy Policy, 39, 5399-5408.

Consentec. (2010). Voraussetzungen einer optimalen Integration erneuerbarer Energien in das Stromversorgungssystem. Studie im Auftrag des Bundesministeriums für Wirtschaft und Technologie (BMWi). Aachen: Consentec and $\mathrm{r} 2 \mathrm{~b}$ Energy Consulting

dena. (2010). dena-Netzstudie II. Integration erneuerbarer Energien in die deutsche Stromversorgung im Zeitraum 2015 - 2020 mit Ausblick 2025. Berlin: Deutsche Energie-Agentur.

dena. (2011, July). Arbeitsgruppe Netzentwicklungsplan, Presentation by Stephan Kohler on 5.72011 at Plenarrunde der Plattform „Zukunftsfähige Energienetze, Berlin. Retrieved from http://www.netzentwicklungsplan.de/sites/default/files/pressematerial/AG_Netz entwicklungsplan.pdf

EEG (2011). Gesetz für den Vorrang Erneuerbarer Energien (Erneuerbare-EnergienGesetz - EEG). http://www.gesetze-im-internet.de/eeg_2009/

Fouquet, D. (2012). Policy instruments for renewable energy - From a European perspective. Renewable Energy, 49, 15-18.

FRG. (2010). National Renewable Energy Action Plan in accordance with Directive 2009/28/EC on the promotion of the use of energy from renewable sources. Berlin: Federal Republic of Germany. Retrieved from http://ec.europa.eu/energy/renewables/action_plan_en.htm

Jahn, D. \& Korolczuk, S. (2012). German exceptionalism: the end of nuclear energy in Germany! Environmental Politics, 21, 159-164.

Langniß, O., Dieckmann, J., \& Lehr, U. (2009). Advanced mechanisms for the promotion of renewable energy - Models for the future evolution of the German Renewable Energy Act. Energy Policy, 37, 1289-1297.

NABEG. (2011). Netzausbaubeschleunigungsgesetz Übertragungsnetz (NABEG). . http://www.gesetze-im-internet.de/bundesrecht/nabeg/

Nagl, S., Fürsch, M., Paulus, M, Richter, J., Trüby, J., \& Lindenberger, D. (2011). Energy policy scenarios to reach challenging climate protection targets in the German electricity sector until 2050. Utilities Policy, 19, 185-192.

Paulus, M. \& Borggrefe, F. (2011). The potential of demand-side management in energy-intensive industries for electricity markets in Germany. Applied Energy, $88,432-441$.

Resenhoeft, V. T. (2011, December 25). Für immer unten. Die Welt. Retrieved from http://www.welt.de/print/wams/vermischtes/article13783226/Fuer-immerunten.html.

Schleicher-Tappeser, R. (2012). How renewables will change electricity markets in the next five years. Energy Policy, 48, 64-77.

SRU. (2010, May). Climate-friendly, reliable, affordable: 100\% renewable electricity supply by 2050 (Statement No. 15). Berlin: German Advisory Council on the Environment. Retrieved from http://www.umweltrat.de/SharedDocs/Downloads/EN/04_Statements/2010_05 _Statement15_Renewablesby2050.pdf?_blob=publicationFile

Verbong, G. P. J., Beemsterboer, S., \& Sengers, F. (2012). Smart grids or smart users? Involving users in developing a low carbon electricity economy. Energy Policy. Retrieved from http://dx.doi.org/10.1016/j.enpol.2012.05.003.

Viebahn, P., Vallentin, D., Höller, S., \& Fischedick, M. (2011) Integrated assessment 
of CCS in the German power plant sector with special emphasis on the competition with renewable energy technologies. Mitigation and Adaptation Strategies for Global Change, 17, 707-730.

Vogel, P. (2009). Efficient investment signals for distributed generation. Energy Policy, 37, 3665-3672

von Hirschhausen, C., Herold, J., \& Oei, P.-Y. (2012). How a 'Low Carbon' Innovation Can Fail - Tales from a 'Lost Decade' for Carbon Capture, Transport, and Sequestration (CCTS). Economics of Energy and Environmental Policy, 1(2).

Wittneben, B. B. F. (2011). The impact of the Fukushima nuclear accident on European energy policy. Environmental Science \& Policy, 15, 1-3. 